\title{
A Clinicohistopathological Correlation of Hysterectomy Specimens in Kashmiri Women Undergoing Elective Abdominal Hysterectomy in a Tertiary Care Centre
}

\author{
Cimona Lyn Saldanha ${ }^{1 *}$, Shabnam Ara ${ }^{2}$, Umrazia Bashir ${ }^{3}$, Abida Ahmad ${ }^{4}$ \\ ${ }^{1 *}$ Associate Professor, ${ }^{2}$ Senior Resident, ${ }^{4}$ Professor, \\ Postgraduate Department of Obstetrics \& Gynaecology, Sher-i-Kashmir Institute of Medical Sciences, Srinagar, J \& K, India. \\ ${ }^{3}$ Consulting Obstetrician Gynaecologist, Dept of OBGYN, Kangan Hospital, Srinagar, J \& K, India.
}

\begin{abstract}
Objective: To study clinical features, indications and histopathological diagnosis of elective abdominal hysterectomy in our region.

Patients and Methods: Patients presenting to our department were worked up for age, presenting symptoms, indications for hysterectomy and histopathology reports of the specimens were analysed. The study was done over a period of two years. Results: A total of 237 elective abdominal hysterectomies were performed. About $99 \%$ of indications of hysterectomy were for benign disease. Peak age incidence was $45-55$ years. $40.92 \%$ of patients presented with menstrual abnormalities, followed by postmenopausal bleeding in $31.22 \%$. On histopathology of uterus $40 \%$ of the patients had leiomyoma, which was most common and $31.22 \%$ had adenomyosis, being second most frequent disease. Endometrial carcinoma in 3 $(1.26 \%)$ patients was least common pathology. There was no mortality associated with the procedure.

Conclusion: Hysterectomy remains acceptable and a successful procedure for management of various uterine pathologies especially in the low resource setting but with proper indication and specific patient counseling. Menstrual
\end{abstract}

\section{INTRODUCTION}

Hysterectomy is one of the most common surgical procedures having a rate of $6.1-8.6 / 1000$ in all ages ${ }^{1}$. It is the definitive cure for many of its indications, which include abnormal uterine bleeding, fibroids, utero-vaginal prolapse, endometriosis and adenomyosis, pelvic inflammatory disease, pelvic pain, gynaecological cancers and obstetric complications ${ }^{2}$. The significance of histo-pathological examination is well established in patients with genital cancer.

The adjuvant treatment depends upon the stage of the disease confirmed by pathological examination. Similarly, the diagnosis of adenomyosis is only established by histo-pathological examination, while AUB is a diagnosis of exclusion. Conversely, many patients may be suspected of having a malignancy on preoperative assessment e.g those with postmenopausal bleeding and histo-pathological examination may aid to rule out this suspicion.

Prevalence of uterine and adnexal pathologies varies from nation to nation and from region to region within the nation ${ }^{3}$. Hence, this study was conducted with an aim of determining the correlation of disturbance is leading indication of hysterectomy and leiomyoma is the commonest pathology in our study in our population studied.

KEYWORDS: Adenomyosis, Elective hysterectomy, Histopathology, Leiomyoma.

\section{${ }^{*}$ Correspondence to:}

Dr. Cimona Lyn Saldanha, Associate Professor, Postgraduate Department of Obstetrics \& Gynaecology, Sher-i-Kashmir Institute of Medical Sciences, Srinagar.

E-mail: clyns@rediffmail.com

Article History:

Received: 02-05-2016, Revised: 12-05-2016, Accepted: 31-05-2016

\begin{tabular}{|l|c|}
\hline \multicolumn{2}{|c|}{ Access this article online } \\
\hline $\begin{array}{l}\text { Website: } \\
\text { www.jmm.com }\end{array}$ & Quick Response code \\
\hline DOI: & \\
10.21276/ijmrp.2016.2.3.030 & \\
\hline
\end{tabular}

indications and histo-pathological diagnosis of elective abdominal hysterectomy in our region.

\section{MATERIALS AND METHODS}

This is a prospective study conducted in the Department of Obstetrics and Gynaecology of Sher-i-Kashmir Institute of Medical Sciences from January 2014 to January 2016. Patients who were presenting to our department with abnormal uterine bleeding symptomatology were subjected to a thorough history taking and examination followed by ultrasonography/ saline infusion salpingography and endometrial biopsy where indicated. After analysis of biopsy reports and taking into consideration the effectiveness of medical treatment and patient counseling, the patients were managed accordingly. Patients who did not respond to conservative management or who expressly wished for a hysterectomy anyway were taken into the study and the parameters including age, parity, presenting symptoms, indications for hysterectomy and histopathology reports were analysed. Emergency and vaginal hysterectomy cases were not included in this study. 


\section{RESULTS}

During the period of two years 237 patients underwent elective abdominal hysterectomy. The patients were distributed over a wide age range (Table 1) of 35 to 75 years. The majority of women $(n=102,43.03 \%)$ were in the age group between 45 and 55 years. All the patients were carefully examined and investigated. The most common presenting symptom (Table 2 \& Fig 1) was menorrhagia $40.92 \%$, pelvic pain $14.76 \%$, both menorrhagia and pelvic pain in $13.08 \%$ and post-menopausal bleeding in $31.22 \%$.

Apart from biochemical tests all the patients had undergone sonography/ saline infusion sonosalpingography of the pelvic organs. In patients of advanced age or where the clinical and radiological findings were not consistent or there was suspicion of malignancy, transvaginal ultrasound and/or CECT abdomen was done.

The most common type of hysterectomy was total abdominal hysterectomy with bilateral salpingo-oophorectomy comprising of 231 cases $(97.46 \%)$ followed by $6(2.54 \%)$ were of total abdominal hysterectomy without salpingo-oophorectomy.

In post-operative period lung atelectasis was seen in 11 (4.64\%), the reason being that these were patients in the older age bracket and they had co morbidities contributing to the complication; wound infection in $9(3.79 \%)$ and pelvic haematomas in two patients who were managed conservatively. There was no mortality.

Table no.1: Age Distribution.

\begin{tabular}{lcc}
\hline Age & Number of Cases & Percentage \\
\hline $\mathbf{3 5 - 4 5}$ & 5 & 2.10 \\
$\mathbf{4 6 - 5 0}$ & 76 & 32.06 \\
$\mathbf{5 1 - 5 5}$ & 102 & 43.04 \\
$\mathbf{5 6 - 6 0}$ & 40 & 16.87 \\
$\mathbf{6 1 - 7 0}$ & 8 & 3.37 \\
$\mathbf{7 1 - 7 5}$ & 6 & 2.53 \\
\hline
\end{tabular}

Table no.2: Presenting complaints.

\begin{tabular}{lcc}
\hline Complaints & Number of Cases & $\%$ \\
\hline Menorrhagia & 97 & 40.92 \\
Pelvic Pain & 35 & 14.76 \\
Menorrhagia + Pelvic & 31 & 13.08 \\
pain & & \\
$\begin{array}{l}\text { Post-menopausal } \\
\text { bleeding }\end{array}$ & 74 & 31.22 \\
\hline
\end{tabular}

Table no.3: Diagnosis on Histopathology

\begin{tabular}{lcc}
\hline $\begin{array}{l}\text { Histopathological } \\
\text { diagnosis }\end{array}$ & $\begin{array}{c}\text { Number of } \\
\text { Cases }\end{array}$ & $\begin{array}{c}\text { Percentage } \\
(\%)\end{array}$ \\
\hline Fibroid Uterus & 95 & 40 \\
Adenomyosis & 74 & 31.22 \\
Endometrial Polyp & 06 & 2.53 \\
Chronic Endometritis & 17 & 7.17 \\
Endometrial & 03 & 1.26 \\
Adenocarcinoma & & \\
Ovarian Cyst & 34 & 14.43 \\
Normal Histology & 08 & 3.37 \\
\hline
\end{tabular}

The histopathological reports were (Table $3 \&$ Fig 2) showing leiomyoma in $95(40 \%)$, endometrial polyp in $6(2.53 \%)$, adenomyosis in $74(31.22 \%)$, chronic endometritis in $17(7.17 \%)$, ovarian cyst in $34(14.43 \%)$ while endometrial carcinoma in 3 $(1.26 \%)$ and normal histology in $8(3.37 \%)$ patients.

\section{DISCUSSION}

Hysterectomy is the most common gynaecological operation performed worldwide 4 . The patients present with varied clinical presentation and age range. In our study the youngest patient was 35 years old while oldest was 74 years old. Peak age incidence of most of the pathologies was $45-55$. This is in accordance to other studies done outside India-7. The commonest presenting symptom in our study was menorrhagia $(40.97 \%)$ followed by pelvic pain (14\%). Mennorhagia is seen to be the most common symptom in other studies as well8-10.

Hysterectomy is indicated for varied spectrum of diseases including benign to malignant pathologies. It is a definite treatment of pelvic pathology including fibroid, abnormal heavy bleeding, chronic pelvic pain, endometriosis, adenomyosis, uterine prolapse, pelvic inflammatory disease and cancer of reproductive organs $^{2}$.
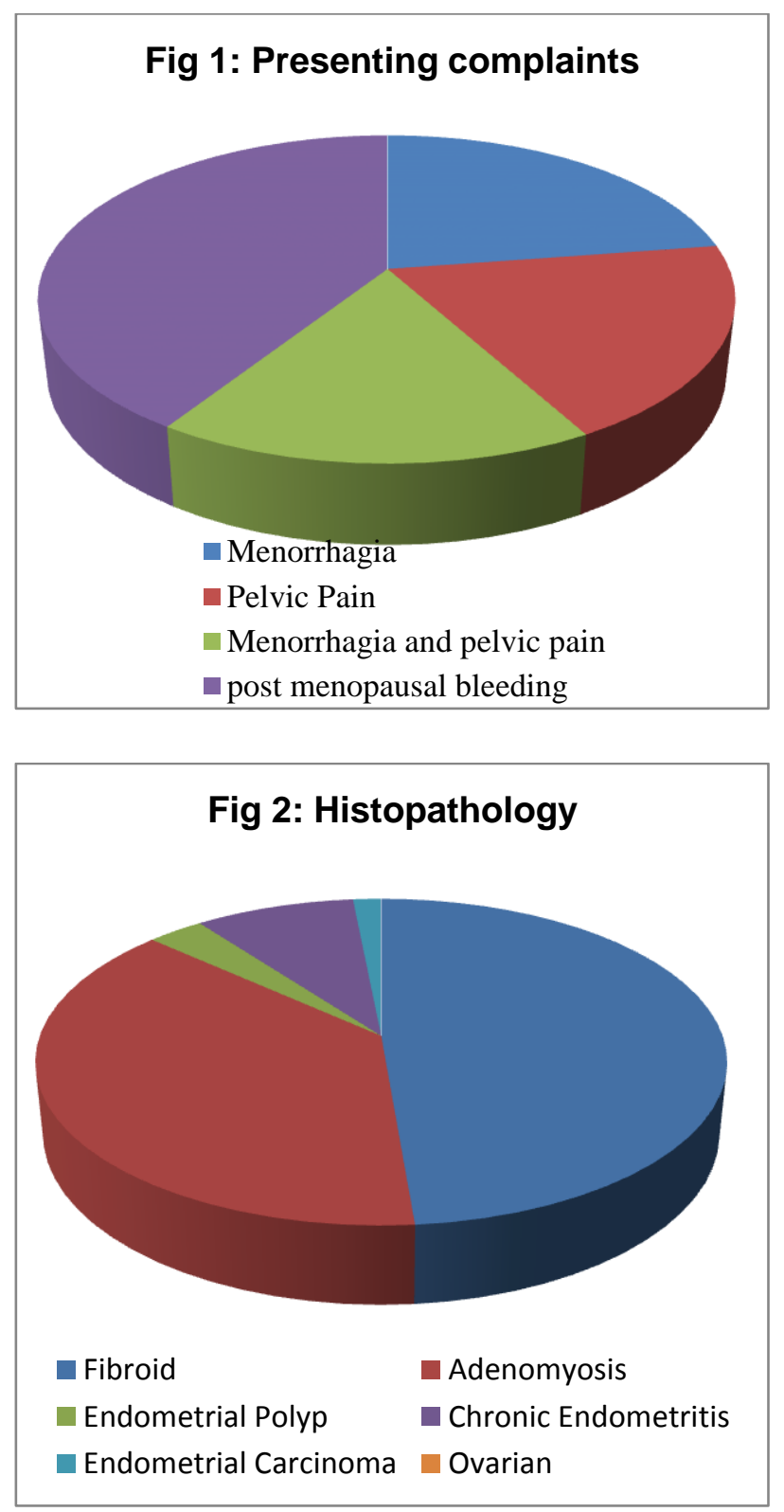
About $99 \%$ of the indications for hysterectomy in our study were benign pathology and most common indication being leiomyoma $(40 \%)$. Uterine malignancies are not so frequent as compared to other gynaecological malignancies in India ${ }^{11}$. In USA $91.7 \%$ hysterectomies are for benign indications ${ }^{12}$. Even though the incidence of malignancy is low, the histopathological examination of the specimen cannot be overlooked as it has heavy bearing in postoperative management.

On histopathology leiomyoma (40\%) was the main pathology followed by adenomyosis (31.2\%). Prevalence of uterine pathologies varies from nation to nation and from region to region within the nation. Incidence of leiomyoma is $25.8 \%$ in Abbah city of Saudi Arabia ${ }^{13}, 78 \%$ in USA ${ }^{14}, 48 \%$ in Nigeria ${ }^{15}$ and $8 \%$ in Sweden ${ }^{16}$. Thus geographical and racial factors have an evident effect on the prevalence of uterine leiomyoma.

Adenomyosis was the second most common histopathological finding in our study (31.22\%). Its incidence in a study done by Shargil SK ${ }^{8}$ is $26 \%$, and in other parts of world like in Pakistan ${ }^{17}$ $24 \%$, in Italian study ${ }^{18} 24.9 \%$ and in West Indies ${ }^{19} 6 \%$. Adenomyosis was found mainly in those who presented menorrhagia. Menstrual disturbance due to adenomyosis is generally refractory to medical treatment and endometrial resection ${ }^{20}$.

\section{CONCLUSION}

Hysterectomy is a highly acceptable and successful treatment modality in developed and more so in developing countries. Menstrual irregularities being the most frequent indication while leiomyoma is the commonest pathology. Histopathology is necessary in confirming diagnosis and thus guiding proper postoperative management, especially of malignant disease.

However it is recommended that patient selection and screening on an individualized basis is of prime importance inclusive of following stringent standard of care, thorough patient counseling and utmost respect of the patient's wishes following this.

\section{REFERENCES}

1. Berek JS. Novak's Gynaecology. Thirteen Edition, Lippincot William \& Wilkins, Philadelphia, Baltimore, New York, London, Sydney, Tokyo, Hong Kong, M Buenos Aeries; 761- 801.

2. Nausheen F, Iqbal J, Bhatti FA, Khan AT, Sheikh S. Hysterectomy. The patient's perspective. Annal Gynecol 2004; 10: 339-41.

3. Rather G R, Gupta Y, Bardhwaj S. Patterns of Lesions in Hysterectomy Specimens: A Prospective Study. JK SCIENCE Vol. 15 No. 2, April - June 2013.

4. Wu JM, Wechter ME, Geller EJ. Hysterectomy rates in the United States 2003. Obstet Gynaecol 2007; 110 (5): 1091-95.

5. Adelusola KA, Ogunniyi SO. Hysterectomies in Nigerians: Histopathological Analysis of Cases Seen in lle Ife. Niger Postgrad Med J 2001; 8 (1): 37-40

6. Sarfraz $T$, Tariq $H$. Histopathological findings in menorrhagia - a study of 100 hysterectomy specimens. Pak J Pathol 2005;16(3):83-5.
7. Perveen S, Tayyab S.Aclinicopathological review of elective abdominal hysterectomy. J Surg Pak 2008; 13 (1): 26-29.

8. Shergill SK, Shergill HK, Gupta M, Kaur S. Clinicopathological study of hysterectomies. J Indian Med Assoc 2002;100(4):238-239.

9. Jamal S, Baqai S.Aclinicohistopathological analysis of 260 Hysterectomies. Pak J Pathol 2001; 12 (2): 11-14.

10. Sobande AA, Eskander M, Archibong EI, Damole IO. Elective hysterectomy: a clinicopathological review from Abha Catchment Area of Saudi Arabia. West Afr J Med 2005; 24 (1): 31-35.

11. Cherian A, Surin C, Jacob S, Prabhakar BR. Primary malignancies of the corpus uteri - retrospective five year analysis. Indian J Pathol Microbiol 1995; 38: 63-72.

12. Clayton RD. Hysterectomy. Best practice \& Research. Clinical Obstet Gynecol 2006;20:73-87 .

13. Sobande AA, Eskander M, Archibong EI, Damole IO. Elective hysterectomy: A clinicopathological review from Abha catchment area of Saudi Arabia. West Afr J Med 2005;24:31-5.

14. Baird DD, Dunson DB, Hill MC, CousinsD, Schectman JM. High cumulative incidence of uterine leiomyoma in black and white women: Ultrasound evidence. Am J Obstet Gynecol 2003;188:100-7.

15. Adelusola KA, Ogunniyi SO. Hysterectomies in Nigerians; histopathological analysis of cases seen in Ile-lfe. Niger Postgrad Med J 2001;8:37-40.

16. Borgfeldt $C$, Andolf $E$. Transvaginal ultrasonographic findings in the uterus and the endometrium: Low prevalence of leiomyoma in a random sample of women age 25-40. Acta Obstet Gynecol Scand 2000;79:202-7.

17. Perveen S, Tayyab S. A Clinicopathological review of elective abdominal hysterectomy Journal of Surgery Pakistan (International) 13 (1) January - March 2008 ; 26-29.

18. Vercellin P. Adenomyosis in hysterectomies: A study on frequency distribution and patient characteristics. Hum Reprod 1995;10:1160-2.

19. Raju GC, Narayn Singh V, Jankey N. Adenomyosis Uteri: A study of 41 cases. Aust NZ J Obstet Gynecol 1988;28:72-3.

20. Ahsan S, Naeem S. A case notes analysis of hysterectomy performed for non-neoplastic indications at Liaquat National Hospital Karachi. J.Pak.Med.Assoc 2001;51:346- 8.

\section{Source of Support: Nil. Conflict of Interest: None Declared.}

Copyright: (c) the author(s) and publisher. IJMRP is an official publication of Ibn Sina Academy of Medieval Medicine \& Sciences, registered in 2001 under Indian Trusts Act, 1882.

This is an open access article distributed under the terms of the Creative Commons Attribution Non-commercial License, which permits unrestricted non-commercial use, distribution, and reproduction in any medium, provided the original work is properly cited.

Cite this article as: Cimona Lyn Saldanha, Shabnam Ara, Umrazia Bashir, Abida Ahmad. A Clinicohistopathological Correlation of Hysterectomy Specimens in Kashmiri Women Undergoing Elective Abdominal Hysterectomy in a Tertiary Care Centre. Int J Med Res Prof. 2016; 2(3):140-42. 